\title{
Antimikrobna osjetljivost uzročnika mastitisa krava s područja sjeverozapadne Hrvatske u razdoblju od 2014. do 2018. godine
}

\author{
T. Sukalič , D. Đuričić, I. Pavljak, A. Končurat, Ž. Cvetnić, J. Grbavac, \\ B. Bačanek, J. Jurmanović $i$ M. Samardžija
}

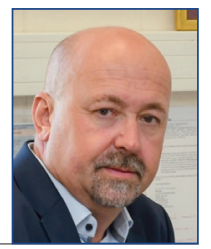

\section{Sažetak}

U ovom su radu prikazani rezultati mikrobioloških pretraga sekreta vimena krava s različitim oblicima upala mliječnih žlijezda. Pretraženi su uzorci tijekom pet godina dostavljani u Laboratorij za dijagnostiku Veterinarskog zavoda Križevci, podrijetlom iz 7 županija sjeverozapadne Hrvatske. Uzorci su pretraženi konvencionalnim mikrobiološkim metodama $u$ aerobnim uvjetima. Ukupno je obrađeno 1264 uzorka, a pozitivan rezultat ustvrđen je u 983 slučaja ili 77,76 \% uzoraka. Pri tome je izdvojeno 967 sojeva bakterija; u 9 slučajeva izdvojene su kvasnice, a u 7 slučajeva alge. Osjetljivost prema antimikrobnim lijekovima određivana je disk-difuzijskom metodom. Od pozitivnih mikrobioloških nalaza $14,24 \%$ izolata pripada vrsti Staphylococcus aureus (S. aureus), a između njih je $60 \%$ rezistentno na OX. Sojevi

S. aureus pokazali su najvišu osjetljivost prema AMC (91,4\%) te prema CEQ $(90,7$ $\%$ ). Koagulaza-negativni stafilokoki (CNS) čine $19,23 \%$ pozitivnih slučajeva, s najboljom osjetljivosti prema CEQ (84,6 \%). Streptococcus agalactiae ustanovljen je u 3,36\% pozitivnih uzoraka, a pokazao je dobru osjetljivost prema CPZ i CEQ (87,9\%). Ostali streptokoki (po Lancefieldovoj grupe C, D i ostale) čine $39,47 \%$ pozitivnih nalaza i pokazali su najbolju osjetljivost prema AMC (95,4\%) i CEQ (92,8 \%). Od Gram-negativnih bakterija među pozitivnim uzorcima najčešće je zastupljena: Escherichia coli $(9,46 \%)$, a zatim rodovi Pseudomonas, Enterobacter i Klebsiella $(3,46 \%, 2,64 \%$ i 0,1 \% kako slijedi). Kvasnice (Candida spp.) i alge (Prototheca spp.) su izdvojene u manje od $1 \%$ slučajeva. Rezultati pokazuju da je postotak stafilokoknih i

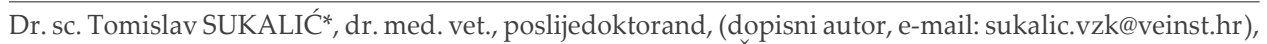
mr. sc. Ivica PAVLJAK, dr. med. vet., asistent, dr. sc. Ana KONČURAT, dr. med. vet., znanstvena suradnica, dr. sc. Željko CVETNIĆ, dr. med. vet., akademik, mr. sc. Branko BAČANEK, dr. med. vet., u mirovini, mr. sc. Jadranka JURMANOVIĆ, dr. med. vet., u mirovini, Hrvatski veterinarski institut - Veterinarski zavod Križevci, Hrvatska; dr. sc. Dražen ĐURIČIĆ, dr. med. vet., docent, Mount-trade, Garešnica, Hrvatska; dr. sc. Jozo GRBAVAC, dr. med. vet., izvanredni profesor, Agronomski i Prehrambeno-biotehnološki fakultet Sveučilišta u Mostaru, Bosna i Hercegovina; dr. sc. Marko SAMARDŽIJA, dr. med. vet., redoviti profesor, Veterinarski fakultet Sveučilišta u Zagrebu, Hrvatska 
streptokoknih mastitisa podjednak onima $\mathrm{u}$ dosadašnjim istraživanjima, no uočen je trend povećanja broja rezistentnih sojeva vrste $S$. aureus. Pouzdan mikrobiološki nalaz $\mathrm{s}$ antibiogramom je uz kliničku pretragu temelj kontrole mastitisa u našim uvjetima, jer različite vrste mikrorganizma zahtijevaju različite pristupe u liječenju, kao što su izbor antibiotika, cijepljenje, zasušivanje četvrti ili kao zadnji izbor izlučenje životinje.

Ključne riječi: mastitis krava, uzročnici mastitisa, antimikrobna osjetljivost, mlijeko

\section{Uvod}

Upala mliječne žlijezde (mastitis) je najčešća bolest mliječnih krava koja ima štetne učinke na dobrobit oboljelih životinja te prouzroči znatne gospodarske gubitke. Veterinari i stočari desetljećima su istraživali učinkovite metode kojima bi se spriječila pojava bolesti, a liječenje je postajalo uspješnije otkrićem penicilina i sulfonamida. Prvi pokusi s intramamarnom aplikacijom penicilina započeli su još 1940. godine i već tada se pokazala bolja osjetljivost streptokoka prema antimikrobnim pripravcima, nego stafilokoka (Ruegg, 2017.). Mastitis se očituje fizikalnim i kemijskim promjenama sekreta i patološkim procesima u parenhimu, čime mlijeko postaje štetno po zdravlje i teladi i ljudi. Uzročnici su najčešće mikroorganizmi, u $95 \%$ slučajeva bakterije (Makek, 1995.) kojih je do danas opisano više od 150 vrsta, a mnoge imaju i zoonotsko značenje. Pogodovni čimbenici za nastanak bolesti su higijena mužnje i higijenske prilike $u$ staji, hranidba te opće zdravstveno stanje životinje. Mastitisi se dijele na kliničke i supkliničke. Dijagnoza kliničkih mastitisa postavlja se temeljem kliničke i mikrobiološke pretrage, dok je kod supkliničkih mastitisa dijagnoza moguća isključivo laboratorijskim pretragama (Radostits i sur., 2000., Quinn i sur., 2003., Benić i sur., 2018.). Infekcija je najčešće galaktogena, vrlo rijetko limfogena ili hematogena, a sluznica cisterne i mliječnih kanala može se $\mathrm{u}$ određenoj mjeri suprotstaviti mikroorganizmima. Obrana je celularna, uz imunološke procese fagocitoze leukocitima koji u fazi upale čine $90 \%$ svih somatskih stanica. Mlijeko zdravih krava sadrži 50000 do 100000 somatskih stanica u $1 \mathrm{~mL}$ i ne sadrži mikroorganizme, a testiranje mastitis reagensom pouzdana je metoda za otkrivanje supkliničikh mastitisa (Radostits i sur., 2000., Tomše-Đuranec i sur., 2008., Maćešić i sur., 2016.).

U dijagnostici mastitisa, PCR tehnika identifikacije mikroorganizama ima širo$\mathrm{ku}$ primjenu, a uvode se i druge metode poput MALDI-TOF MS (Pieper i sur., 2012., El-Jakee i sur., 2013., Hiitiö i sur., 2015.). RT-PCR rutinski identificira 12 ili više najučestalijih bakterijskih vrsta i istovremeno identificira uzročnike koji imaju gen odgovoran za produkciju enzima $\beta$-laktamaze. Istraživanjima dinamike intramamarnih infekcija u laktaciji pokazalo se da glavnu ulogu imaju bakterije iz okoliša, ali je još uvijek manje poznato značenje i patogeneza algi, kvasaca i plijesni, koji se mogu naći u upalno promijenjenom vimenu, kao i mogućnosti njihovog liječenja (Quinn i sur., 1999., Malinovski i sur., 2002., Stepanić i sur., 2014., Ruegg, 2017., Cobo-Angel i sur., 2018.). Cvetnić i sur. (2016.a) kao najčešće izdvojene patogene bakterije navode S. aureus, Streptococcus spp., Trueperella pyogenes i Corynebacterium bovis. Uspjeh terapije mastitisa, osim o vrsti uzročnika ovisi o više čimbenika a to mogu biti: dužina trajanja infekcije, stupanj oštećenja tkiva i općenito kondicija životinje. Blaga i umjerena upala mliječne žlijezde liječe se lokalno, dok je kod težih upala potrebno primijeniti i parenteralnu terapiju uz analgetike, imunostimulatore, vitamine i 
infuziju. Suhostajna terapija se provodi na temelju mikrobiološkog nalaza, intramamarnom primjenom antimikrobnih pripravaka, a za neke uzročnike i predsuhostajnom petodnevnom parenteralnom aplikacijom prokain-penicilina, gentamicina, enrofloksacina ili florfenicola. Istraživanja provedena na Prototheca sp. upućuju na osjetljivost prema nistatinu i gentamicinu , in vitro" (Malinovski i sur., 2002., Taponen i sur., 2003., Saini i sur., 2012., Wawron i sur., 2013., Stepanić i sur., 2014., Krömker i Leimbach, 2017.). Krave s atrofičnim četvrtima treba izlučiti iz stada, ali moguće ih je i ciljano trajno zasušiti na način da se primjenom $60 \mathrm{~mL}$ $2 \%$ klorheksidina, $60 \mathrm{~mL} 3 \%$ srebrnog nitrata ili $20 \mathrm{~mL} 5 \%$ bakrenog sulfata izazove tzv. kemijski mastitis ili „slijepa četvrt". Tim postupkom životinja ostaje u proizvodnji, a izvor infekcije se ukloni (Radostits i sur., 2000., Stepanić i sur., 2014.). U brojnim istraživanjima razvijane su antimastitis strategije, uvođenjem alternativnih lijekova poput zeolita klinoptilolita, ozona, propolisa, biljnih derivata, bakteriofaga, proteina karakterističnih za upale, laktoferina i srebrnih nanočestica (Gomes i Henriques, 2015., Bačić i sur., 2016., Jamaran i Zarif, 2016., Benić i sur., 2018., Đuričić i sur., 2020.). Unatoč svemu, pojava rezistentnih sojeva postala je globalni zdravstveni problem, a uporaba antibiotika pri liječe- nju mastitisa još uvijek je neophodna. Naputcima OIE (2019.) i Smjernicama EU (2015.) traži se uspostavljanje Nacionalne strategije rješavanja antimikrobne rezistencije (Gomes i Henriques, 2016., Lömker i Leimbach, 2017.).

Svrha je ovog istraživanja bila prikazati rezultate mikrobioloških pretraga sekreta vimena krava prikupljenih tijekom 5 godina s područja sjeverozapadne $\mathrm{Hr}$ vatske, usporediti rezultate antimikrobne osjetljivosti s dosadašnjim istraživanjima te procijeniti pojavnost rezistentnih bakterijskih sojeva. Rezultati će se moći iskoristiti pri liječenju perakutnih i akutnih mastitisa te smatramo da će ovo istraživanje doprinijeti upoznavanju etiologije mastitisa i još jednom istaknuti važnost mastitisa i primjene ciljane antimikrobne terapije.

\section{Materijali i metode}

Uzorci sekreta vimena pretraženi $\mathrm{u}$ ovom istraživanju dostavljeni su $\mathrm{u}$ Laboratorij za dijagnostiku Veterinarskog zavoda Križevci, u razdoblju od 2014. do 2018. godine od strane terenskih veterinara ili vlasnika životinja, u sterilnim epruvetama. Ukupno je pretraženo 1264 uzorka s područja šest županija i grada Zagreba. Broj i teritorijalni raspored obrađenih uzoraka prikazan je u tabeli 1 .

Tabela 1. Uzorci sekreta vimena obrađeni u istraživanju

\begin{tabular}{|l|c|c|c|c|c|c|}
\hline Županija & $\mathbf{2 0 1 4 .}$ & $\mathbf{2 0 1 5 .}$ & $\mathbf{2 0 1 6 .}$ & $\mathbf{2 0 1 7 .}$ & $\mathbf{2 0 1 8 .}$ & Ukupno \\
\hline Bjelovarsko-bilogorska & 56 & 57 & 192 & 86 & 70 & 461 \\
\hline Koprivničko-križevačka & 199 & 172 & 137 & 145 & 95 & $\mathbf{7 4 8}$ \\
\hline Međimurska & 9 & & & & & 9 \\
\hline Varaždinska & 3 & 2 & & 1 & & 6 \\
\hline Virovitičko-podravska & 4 & & & 3 & & 7 \\
\hline Zagrebačka & 5 & 6 & 7 & 3 & 4 & 25 \\
\hline Grad Zagreb & 3 & 5 & & & & 8 \\
\hline Ukupno & 279 & 242 & 336 & 238 & 169 & 1264 \\
\hline
\end{tabular}


Uzorci su po zaprimanju pretraženi Zagrebačkim mastitis reagensom (Hrvatski veterinarski institut, Zagreb, Hrvatska) te su po procjeni reakcije nacijepljeni na prikladne hranjive podloge. U svrhu izdvajanja patogenih bakterija korištene su konvencionalne bakteriološke metode (Quinn i sur., 2003.). Kao osnovna podloga korišteni su krvni agar ili Columbia agar („Merck“)

Tabela 2. Antimikrobni pripravci korišteni u istraživanju

\begin{tabular}{|l|c|c|c|}
\hline ANTIMIKROBNI LIJEK & OZNAKA & $\begin{array}{c}\text { SADRŽAJ DISKA } \\
\text { (KONCENTRACIJA) }\end{array}$ & PROIZVOĐAČ \\
\hline Penicilin & P & $6 \mu \mathrm{g} / 10 \mathrm{~J}$ & OXOID \\
\hline Oksacilin & OX & $1 \mu \mathrm{g}$ & OXOID \\
\hline Amoksicilin/Klavulanska kiselina & $\mathrm{AMC}$ & $20 / 10 \mu \mathrm{g}$ & BIO-RAD \\
\hline Cefaleksin & $\mathrm{CFX}$ & $30 \mu \mathrm{g}$ & BIO-RAD \\
\hline Cefoperazon & $\mathrm{CPZ}$ & $30 \mu \mathrm{g}$ & OXOID \\
\hline Cefquinom & $\mathrm{CEQ}$ & $30 \mu \mathrm{g}$ & OXOID \\
\hline Enrofloksacin & ENF & $5 \mu \mathrm{g}$ & OXOID \\
\hline Sulfametoksazol/Trimetoprim & SXT & $25 / 75 \mu \mathrm{g}$ & MAST DIAGNOSTICS \\
\hline Oksitetraciklin & OT & $30 \mu \mathrm{g}$ & MAST DIAGNOSTICS \\
\hline Gentamicin & $\mathrm{GM}$ & $15 \mu \mathrm{g}$ & OXOID \\
\hline linkomicin/neomicin & LN & $30 \mu \mathrm{g}$ & OXOID \\
\hline
\end{tabular}

Tabela 3. Mikroorganizmi izdvojeni iz uzoraka u istraživanju

\begin{tabular}{|l|c|c|c|}
\hline Vrsta uzročnika & Oznaka/kratica & Broj izdvojenih & \% izdvojenih \\
\hline Streptococcus spp. & SCS & 388 & 30,69 \\
\hline Staphylococcus spp. (CNS) & CNS & 189 & 14,95 \\
\hline Staphylococcus aureus & SAU & 140 & 11,07 \\
\hline Escherichia coli & ESC & 93 & 7,35 \\
\hline Bacillus spp. & BAC & 35 & 2,76 \\
\hline Pseudomonas spp. & PSE & 34 & 2,69 \\
\hline Streptococcus agalactiae & SCA & 33 & 2,61 \\
\hline Enterobacter spp. & ENB & 26 & 2,05 \\
\hline Micrococccus spp. & MCC & 15 & 1,18 \\
\hline Corynebacterium spp. & COR & 13 & 1,02 \\
\hline Candida spp. & CAN & 9 & 0,71 \\
\hline Prototheca spp. & PRT & 7 & 0,55 \\
\hline Klebsiella spp. & KLE & 1 & 0,08 \\
\hline Ukupno pozitivno & & 983 & 77,76 \\
\hline Negativno / mješovita mikroflora & & 281 & 22,24 \\
\hline Ukupno pretraženo & & 1264 & \\
\hline
\end{tabular}


s $5 \%$ defibrinirane ovčje krvi, kako bi se ustanovile morfološke karakteristike i hemolitičke osobine pojedinih izolata. Kulture su inkubirane aerobno na 37 ${ }^{\circ} \mathrm{C} / 24-48$ sati. U svrhu izdvajanja kvasnica korišten je Sabouraud maltoza agar („Merck"; suplement kloramfenikol 50 $\mathrm{mg} / \mathrm{L}$ ) uz aerobnu kultivaciju na $30^{\circ} \mathrm{C} / 2-7$ dana. Porasle kolonije mikroorganizama identificirane su u skladu sa standardnim preporukama opisanim $\mathrm{u}$ Laboratory handbook on bovine mastitis (NMC, 1999.), a po potrebi je korišten i „Vitek-2“ ID sustav („BioMerieux“). Osjetljivost izdvojenih sojeva prema antimikrobnim lijekovima provedena je disk-difuzijskom metodom na Mueller-Hinton agaru, direktnom suspenzijom kolonija uz 0,5 McFarland, prema standardu Clinical and Laboratory Standards Institute M02-A12 (CLSI, 2015.), a testirani diskovi prikazani su u tabeli 2. Zone inhibicije za antimikrobne pripravke procijenjene su sukladno dodatku za antimikrobno testiranje M100-S25 (CLSI, 2015.).

\section{Rezultati i rasprava}

Mikrobiološkim pretragama iz dostavljenih 1264 uzoraka sekreta vimena izdvojeno je 13 različitih vrsta mikroorganizama, a pozitivan rezultat pretrage dobiven je $\mathrm{u}$ 983 ili 77,76 \% slučajeva. U 22,24 \% slučajeva rezultat pretrage bio je negativan ili je izdvojena mješovita mikroflora (Tabela 3 ).

Između pozitivnih uzoraka (Grafikon 1) najčešće su zastupljeni streptokoki, u ukupno 42,83 \% uzoraka, od čega Streptococcus spp. (grupa C, D i ostali) čini $39,47 \%$, a Streptococcus agalactiae (S. agalactiae) 3,36 \% pozitivnih. Slijede stafilokoki koji su izdvojeni u 33,47 \% slučajeva; koagulaza-negativni Staphylococcus spp. u $19,23 \%$ i $S$. aureus u $14,24 \%$. Od ostalih uzročnika mastitisa, značajnije je zastupljena Escherichia coli (E. coli) koja čini 9,46\% pozitivnih uzoraka, dok su ostali ustanovljeni u nižim postotcima.

Izdvojene bakterijske kulture testirane su na antimikrobnu osjetljivost, a rezultati su prikazani u tabeli 4 .

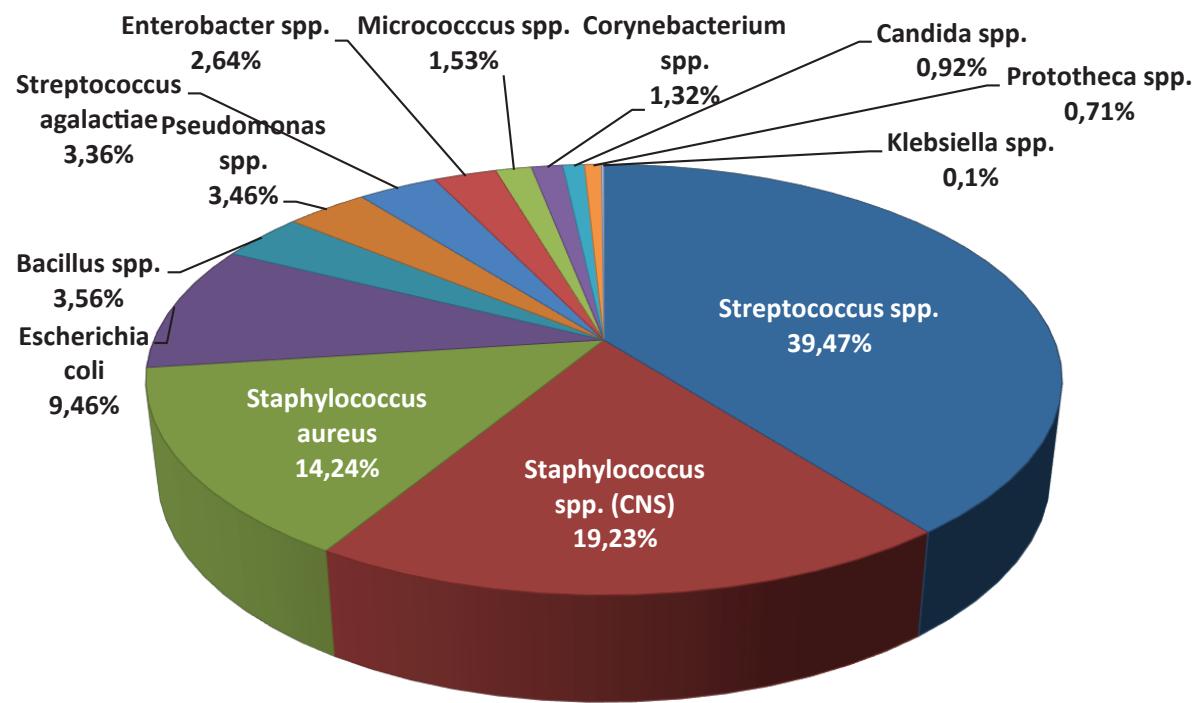

Pozitivni uzorci: $n=983$

Grafikon 1. Odnos izdvojenih mikroorganizama među pozitivnim uzorcima 
Tabela 4. Prikaz antimikrobne osjetljivosti izdvojenih bakterijskih sojeva, prema vrstama

\begin{tabular}{|c|c|c|c|c|c|c|c|c|c|c|c|}
\hline \multirow{3}{*}{ Uzročnik } & \multicolumn{11}{|c|}{ Antimikrobni pripravak } \\
\hline & $P$ & $0 x$ & AMC & CXN & $\mathrm{CPZ}$ & CEQ & ENR & SXT & OT & GM & LN \\
\hline & \multicolumn{11}{|c|}{ Osjetljivost u \% } \\
\hline SAU & 48,6 & 40 & 91,4 & 71,4 & 84,3 & 90,7 & 88,6 & 54,3 & 37,8 & NT & 68,6 \\
\hline CNS & 49,7 & 35,9 & 83,1 & 58,7 & 79,9 & 84,6 & 82 & 46,6 & 20,1 & NT & 49,2 \\
\hline MCC & 40 & 46,7 & 93,3 & 80,0 & 86,7 & 100 & 53,3 & 33,3 & 33,3 & NT & 73,3 \\
\hline SCA & 63,6 & 42,4 & 84,8 & 60,6 & 87,9 & 87,9 & 63,6 & 36,4 & 21,2 & NT & 66,7 \\
\hline SCS & 59,8 & 43,3 & 95,4 & 72,7 & 87,4 & 92,8 & 64,4 & 48,5 & 33,7 & NT & 51,8 \\
\hline BAC & 22,9 & 5,7 & 25,7 & 17,1 & 31,4 & 14,3 & 94,3 & 42,9 & 22,9 & NT & 57,1 \\
\hline ESC & NT & NT & 50,5 & 22,6 & 72 & 75,3 & 80,6 & 30,1 & 21,5 & 17,2 & 29 \\
\hline ENB & NT & NT & 61,5 & 15,4 & 84,6 & 84,6 & 92,3 & 19,2 & NT & 30,8 & 38,5 \\
\hline PSE & NT & NT & NT & NT & 88,2 & 85,3 & 79,4 & 5,9 & NT & 44,1 & 26,5 \\
\hline KLE & NT & NT & 100 & 100 & 100 & 100 & 100 & NT & NT & 100 & 100 \\
\hline COR & 92,3 & 76,9 & 100 & 100 & 100 & 84,6 & 69,2 & 23,1 & 30,8 & NT & 30,8 \\
\hline PRT & NT & NT & NT & NT & NT & NT & NT & NT & NT & 42,8 & NT \\
\hline
\end{tabular}

Kratice antimikrobnih pripravaka navedene u tabela 2. Kratice uzročnika mastitisa navedene u tabeli 3. NT - nije testirano

Iz tabele 4 vidljivo je da su rezistentni sojevi ustvrđeni kod većine izdvojenih bakterijskih vrsta, a Gram-negativne bakterije (uz izuzetak Klebsiella spp.) u pravilu pokazuju veću rezistenciju od Gram-pozitivnih bakterija.

Udio pozitivnih nalaza ustvrđenih $\mathrm{u}$ našem istraživanju $(77,76 \%)$ odgovara istraživanjima provedenim u Kanadi i skandinavskim zemljama (Makovec i Ruegg, 2003., Pitkälä i sur., 2004.), dok su više pozitivnih uzoraka $(85,7 \%)$ ustvrdili u Finskoj Hiitiö i sur. (2015.), a manje $u$ Njemačkoj Tenhagen i sur. (2006.). Najčešće izdvajani uzročnici u ovom istraživanju bili su streptokoki grupe C, D i ostali (388 sojeva ili $39,47 \%$ ), što je približno rezultatu od $44,7 \%$ koji objavljuju Cvetnić i sur. (2016.b). Makovec i Ruegg (2003.) okolišne streptokoke izdvojili su iz 20,1 \% uzoraka. Rezultat od 3,36 \% pozitivnih na S. agalactiae, gotovo je identičan rezultatu od 3,0 \% kojeg su objavili Makovec i
Ruegg (2003.). Svennesen i sur. (2018.) ustvrdili su $S$. agalactiae u $7,4 \%$ pozitivnih uzoraka, što je više nego dvostruko od našeg istraživanja, a višestruko manje (0,4\%) ustvrdili su Cvetnić i sur. (2016.b) te Hiitiö i sur., (2015.) (0,34 \%). Najviši postotak uzoraka pozitivnih pozitivnih nalaza na $S$. agalactiae $(17,39 \%)$ ustvrdio je Burović (2020.). S. aureus izdvojen je iz 140 uzoraka $(14,24 \%)$, što je slično izvješćima drugih autora. Tako su 15,5 \% pozitivnih na $S$. aureus ustanovili Cvetnić i sur. (2016.b), 17,7\% Mekovec i Ruegg (2003.), 10,2 \% Pitkälä i sur. (2004.) te 8,1 \% Svennesen i sur. (2018.) u Danskoj. Najveći postotak pozitivnih na $S$. aureus ustvrdili su Burović (2020.) i Hiitiö i sur. (2015.), kako slijedi 21,74\% i 24,8\%. Patogenost $S$. aureus i uloga u patogenezi mastitisa uvelike ovise o prisutnosti $i c a A$ i icaD gena koji kontroliraju produkciju sluzi i mogućnost stvaranja biofilma (Saidi i sur., 2021.). Koagulaza negativni stafilokoki (CNS) zastupljeni 
su u našem istraživanju s 19,24 \% među pozitivnim uzorcima, što je približno jednako rezultatu od 17,5\% kojeg su dobili Makovec i Ruegg (2003.). Višu zastupljenost CNS (21,7 \%) prikazali su El-Jakee i sur. (2013.) u istraživanju provedenom u Egiptu, a manju (9,1\%) Tenhagen i sur. (2006.) u Njemačkoj te 5,3\% Cvetnić i sur. (2016.b) u Hrvatskoj.

Mastitisi niske pojavnosti s prevalencijom manjom od $10 \%$ pojavljuju se u svim fazama laktacije i u suhostaju. Klebsiella spp. nađena je u $0,1 \%$ naših uzoraka, a više izolata od nas (1,2\%) imali su Makoveci Ruegg (2003.). Vrstu Candida spp. izdvojili smo iz 0,9 \% uzoraka, dok su tu vrstu Cvetnić i sur. (2016.b) ustvrdili u 3,3 \% uzoraka. U Kanadi je prevalencija za Prototheca spp. 5,1 \% (Pieper i sur., 2012.), za razliku od naših nalaza, gdje je Prototheca spp. zastupljena sa svega 0,7\%. Prema navodima Stepanić i sur. (2014.), Prototheca spp. se u novije vrijeme sve ćešće izdvaja tijekom rutinskih pretraga. Đuričić i sur. (2020.) izdvojili su Prototheca spp. i kvasnice $u$ istom postotku $(1,16 \%)$.

Promatrajući rezultate antibiograma za pojedine vrste mikroorganizama prikazane u tabeli 4, vidljivo je da je najviše sojeva vrste $S$. aureus osjetljivo prema AMC (91,4 \%). Od cefalosporina osjetljiviji su prema CEQ (90,7 \%) nego prema CPZ (84,3\%), a visoku osjetljivost pokazali su još prema ENR (88,6\%). Manje od $50 \%$ sojeva $S$. aureus pokazalo je osjetljivost prema $\mathrm{P}(48,6 \%)$ i OX $(40,0 \%)$, a najnižu osjetljivost pokazali su prema OTC (37,8 \%). U našim ranijim radovima (Jurmanović i sur., 2012.) osjetljivost prema OX bila je od $66,7 \%$ u 2007. do 88,6 \% u 2010. godini, što ukazuje na trend povećanja OXrezistentnih sojeva $S$. aureus u Hrvatskoj, između dva istraživanja u razdoblju od 10 godina. Rezistencija prema OX u svijetu je prosječno $50 \%$. U Kanadi se kreće od $7 \%$ do $63 \%$ (Saini i sur., 2012.), u Finskoj 52,1 \% (Pitkälä i sur., 2004.) do 67 \% (Taponen i sur., 2003.), a u Turskoj
$55,9 \%$ (Turutoglu i sur., 2006.), što je sukladno rezultatima ovog istraživanja. Jurmanović i sur. (2012.) nadalje navode osjetljivost $S$. aureus prema CPZ $100 \% \mathrm{u}$ 2007. godini, a prema AMC 95,7\%, dok su Benić i sur. (2003.) ustvrdili za vrstu S. aureus $100 \%$ osjetljivost prema AMC i $95 \%$ prema CPZ.

Najveći broj sojeva CNS bio je osjetljiv prema CEQ $(84,6 \%)$, dok je prema $\mathrm{P}$ $46,6 \%$ osjetljivih sojeva. Slične rezultate objavljuju i drugi autori (Erskine i sur., 2002., Pitkälä i sur., 2004., Turutoglu i sur., 2006.). Najslabiju osjetljivost, CNS su pokazali prema OT (20,1 \%).

Streptococcus spp. pokazao je visoku osjetljivost prema AMC te CEQ i CPZ, kako slijedi $95,4 \%, 92,8 \%$ i 87,4 \%, dok je za $S$. agalactiae ustvrđena istovjetna osjetljivost prema CEQ i CPZ $(87,9 \%)$ i tek nešto niža prema AMC $(84,8 \%)$.

Najviše osjetljivih sojeva E. coli $(80,6 \%)$ bilo je prema ENR; prema cefalosporinima su pokazali osjetljivost $72 \%-75,3 \%$, a prema AMC 50,5\%. Drugi autori u Hrvatskoj i svijetu objavljuju slične rezultate (Erskine i sur., 2002., Makovec i Ruegg, 2003., Hiitiö i sur., 2015., Cvetnić i sur., 2016.b). Naše istraživanje potvrdilo je navode o osjetljivosti Prothoteca spp. prema GM, no ona je svega $42,8 \%$.

\section{Zaključak}

Pouzdani mikrobiološki nalaz s određivanjem antimikrobne osjetljivosti je uz kliničku pretragu temelj kontrole mastitisa, jer različite vrste izdvojenih mikrorganizma zahtijevaju i različitu strategiju terapije, od izbora antibiotika, načina liječenja i cijepljenja, do odluka o eventualnom zasušivanju četvrti ili izlučenju životinje.

Naši rezultati pokazuju da je broj stafilokoknih i streptokoknih mastitisa sličan rezultatima drugih autora, ali i da postoji trend povećanja broja rezistentnih sojeva vrste $S$. aureus. Rezistentni 
sojevi ustvrđeni su i kod većine ostalih izdvojenih bakterijskih vrsta; od Grampozitivnih najviše kod Bacillus spp., a od Gram-negativnih bakterija kod vrste E. coli. Navedene činjenice ukazuju na potrebu daljnjih istraživanja i povećanu pozornost, a ponajprije $\mathrm{s}$ javnozdravstvenog i ekonomskog gledišta.

\section{Literatura}

1. BAČIĆ, I., N. MAČEŠIĆ, L. RADIN, J. ALADROVIĆ, K. MATANOVIĆ, T. MAŠEK, D. BROZIĆ, M. BENIĆ, B. RADIĆ, J. ŠURAN, M. EFENDIĆ, J. DAUD, A. KOSTELIĆ i G. BAČIĆ (2016): Preliminarni rezultati aplikacije intramamarne otopine propolisa (3\% i 5\%) u svrhu liječenja mastitisa na farmi mliječnih krava Krndija. Zbornik 6. Hrvatski veterinarski kongres, Opatija 2016., str. 551-558.

2. BENIĆ, M., M. LOJKIĆ, D. MAJNARIĆ i Ž. MIHALJEVIĆ (2003): In vitro osjetljivost uzročnika mastitisa na antimikrobne tvari. Zbornik radova IV srednjoeuropski bujatrički kongres, Lovran, pp. 125-130.

3. BENIĆ, M., N. MAČEŠIĆ, L. CVETNIĆ, B. HABRUN, Ž. CVETNIĆ, R. TURK, D. ĐURIČIĆ, M. LOJKIĆ, V. DOBRANIĆ, H. VALPOTIĆ, J. GRIZELJ, D. GRAČNER, J. GRBAVAC and M. SAMARDŽIJA (2018): Bovine mastitis: a persistent and evolving problem requiring novel approaches for its control - a review. Vet. arhiv 88, 535-557.

4. BUROVIĆ, J. (2020): Isolation of bovine clinical mastitis bacterial pathogens and their antimicrobial susceptibility in the Zenica region in 2017. Vet. stn. 51, 47-52. (In Croatian).

5. Clinical and Laboratory Standards Institute (2015): M02-A12 Performance Standards for Antimicrobial Disk Susceptibility Tests; Approved StandardTwelfth Edition.

6. Clinical and Laboratory Standards Institute (2015): M100-S25 Performance Standards for Antimicrobial Susceptibility Testing; Twenty-Fifth Informational Supplement.

7. COBO - ANGEL, C., A. S. JARAMILLOJARAMILLO, L. M. LASSO-ROJAS, S. B. AGUILARMARIN, J. SANCHEZ, J. C. RODRIGUEZLECOMPTE, A. CEBALLOS-MARQUEZ and R. N. ZADOKS (2018): Streptococcus agalactiae is not always an obligate intramammary pathogen: Molecular epidemiology of GBS from milk, feces and environment in Colombian dairy herds. Plos One 13(12): e0208990. DOI: 101371/journal. pone.0208990.

8. CVETNIĆ, L., M. SAMARDŽIJA, B. HABRUN, G. KOMPES and M. BENIĆ (2016a): Microbiological monitoring of mastitis pathogens in the control of udder health in dairy cows. Slov. Vet. Res. 53, 131-140.

9. CVETNIĆ, L., M. BENIĆ, B. HABRUN, G. KOMPES, M. STEPANIĆ i M. SAMARDŽIJA (2016b): Najčešći uzročnici mastitisa u krava i koza u Republici Hrvatskoj. Vet. stn. 47, 109-116.

10. ĐURIČIĆ, D., T. SUKALIĆ, F. MARKOVIĆ, P. KOČILA, I. ŽURA ŽAJA, S. MENČIK, T. DOBRANIĆ, M. BENIĆ and M. SAMARDŽIJA (2020): Effects of Dietary Vibroactivated Clinoptilolite Supplementation on the Intramammary Microbiological Findings in Dairy Cows. Animals 10, 202; doi:10.3390/ ani10020202

11. EL-JAKEE, J. K., E. A. NOHA, A. GOMAA, M. D. EL-HARIRI, H. M. GALAL, S. A. OMAR and A. SAMIR (2013): Emerging of coagulase negative staphylococci as a cause of mastitis in dairy animals: An environmental hazard. Int. J. Vet. Sci. Med. I, 74-78.

12. ERSKINE, R. J., R. D. WALKER, C. A. BOLIN, P. C. BARTLETT and D. G. WHITE (2002): Trends in Antibacterial Susceptibility of Mastitis Pathogens during a Seven-Year Period. J. Dairy Sci. 85, 1111-1118.

13. GOMES, F. and M. HENRIQUES (2016): Control of Bovine Mastitis: Old and Recent Therapeutic Approaches. Curr. Microbiol. 72, 377-382.

14. HIITIÖ, H., R. RIVA, T. AUTIO, T. POHJANVIRTA, J. HOLOPAINEN, S. PYÖRÄLÄ and S. PELKONEN (2015): Performance of a real-Time PCR assay in routine bovine mastitis diagnostics compared with in-depth convencional culture. J. Dairy Res. 82, 200-208.

15. JAMARAN, S. and B. H. ZARIF (2016): Synergistic Effect of Silver Nanoparticles with Neomycin or Gentamicin Antibiotics on Mastitis-Causing Staphylococcus aureus. Open Journal of Ecology 6, 452-459.

16. JURMANOVIĆ, J., B. BAČANEK, I. PAVLJAK, T. SUKALIĆ, V. JAKI, D. MAJNARIĆ, A KONČURAT i J. SOKOLOVIĆ (2012): Osjetljivost na antimikrobne tvari sojeva Staphylococcus aureus izdvojenih iz mlijeka krava s upalom mliječne žlijezde. Rad HAZU 37, 105-111.

17. KRÖMKER, V. and S. LEIMBACH (2017): Mastitis treatment - Reduction in antibiotic usage in dairy cows. Reprod. Domest. Anim. 52 (suppl. 3): 21-29.

18. MAĆEŠIĆ, N., G. BAČIĆ, K. BOŽIČEVIĆ, M. BENIĆ, T. KARADJOLE, N. PRVANOVIĆ BABIĆ, M. LOJKIĆ, M. EFENDIĆ, I. BAČAIĆ and M. PAVLAK (2016): Assessment of the Zagreb mastitis test in diagnosis of subclinical mastitis in dairy cattle. Vet. arhiv 86, 475-485.

19. MAKEK, Z. (1995): Osvrt na dijagnostiku, terapiju i preventivu upala mliječne žlijezde u krava. Mljekarstvo 45, 275-282.

20. MAKOVEC, J. A. and P. L. RUEGG (2003): Results of Milk Samples Submitted for Microbiological Examination in Wisconsin from 1994 to 2001. J. Dairy Sci. 86, 3466-3472. 
21. MALINOVSKI, E., H. LASSA and A. KLOSSOWSKA (2002): Isolation of Prototheca zopfii from inflamed secretion of udders. Bull. Vet. Inst. Pullawy 46, 295-299.

22. NATIONAL MASTITIS COUNCIL (1999): Laboratory handbook on bovine mastitis, NMC Inc., Madison, WI 53704-6797, USA, Revised edition.

23. Official Journal of the European Union (2015): Guidelines for the prudent use of antimicrobials in veterinary medicine. Commission notice 2015/C 299/04. https://ec.europa.eu/health/sites/health/ files/antimicrobial_resistance/docs/2015_prudent_ use_guidelines_en.pdf

24. OIE (2019): Responsible and prudent use of antimicrobial agents in veterinary medicine. In: Terrestrial Animal Health Code. Chapter 6.10. https://www.oie.int/ fileadmin/Home/eng/Health_ standards/tahc/current/chapitre_antibio_use.pdf

25. PIEPER, L., A. GODKIN, U. ROESLER, A. POLLEICHTNER, D. SLAVIC, K. E. LESLIE and D. F. KELTON (2012): Herd characteristics and cowlevel factors associated with Prototheca mastitis on dairy farms in Ontario, Canada. J. Dairy Sci. 95, 5635-5644.

26. PITKÄL ̈̈, A., M. HAVERI, S. PYÖRÄL ̈̈, V. MYLLYS and T. HONAKANEN-BUZALSKI (2004): Bovine Mastitis in Finland 2001 - Prevalence, Distribution of Bacteria, and Antimicrobial Resistance. J. Dairy Sci. 87, 2433-2441.

27. QUINN, P. J., B. K. MARKEY, M. E. CARTER, W. J. DONNELLY and F. C. LEONARD (2003): Veterinary Microbiology and Microbial Disease. $4^{\text {th }}$ ed., pp. 465-475.

28. QUINN, P. J., M. E. CARTER., B. MARKEY and G. R. CARTER (1999): Clinical Veterinary Microbiology. $3^{\text {rd }}$ ed., pp. 95-103; pp. 327-344.

29. RADOSTITS, O. M., C. C. GAY, D. C. BLOOD and K. W. HINCHCLIFF (2000): A Textbook of Diseases of Cattle, Sheep, Pigs, Goats and Horses, $9^{\text {th }}$ ed., pp. 603-700.

30. RUEGG, P. L. (2017): A 100-Year Review: Mastitis detection, management and prevention. J. Dairy Sci. 100, 10381-10397.

31. SAIDI, R., Z. CANTEKIN, N. MIMOUNE, Y. ERGUN, H. SOLMAZ, D. KHELEF and R. KAIDI (2021): Investigation of the presence slime production, VanA gene and antiseptic resistance genes in Staphylococci isolated from bovine mastitis in Algeria. Vet. stn. 52, 57-63.

32. SAINI, V., J. T. McCLURE, D. T. SCHOLL, T. J. DEVRIES and H. W. BARKEMA (2012): Herdlevel association between antimicrobial use and antimicrobial resistance in bovine mastitis Staphylococcus aureus isolates on Canadian dairy farms. J. Dairy Sci. 95, 1921-1929.

33. STEPANIĆ, M., M. BENIĆ, B. HABRUN, G. KOMPES i M. PERKOVIĆ (2014): Uzročnici mastitisa niske pojavnosti. Vet. stn. 45, 41-47.

34. SVENNESEN, L., S. S. NIELSEN, Y. S. MAHMMOD, V. KRÖMKER, K. PEDERSEN and I. C. KLAAS (2018): Associaton between teat skin colonization and intramammary infection with Staphylococcus aureus and Streptococcus agalactaiae in herds with automatic milking systems. J. Dairy Sci. 102, 629-639.

35. TAPONEN, S., A. JANTUNEN, E. PYÖR̈̈LÄ and S. PYÖRÄLÄ ( 2003): Efficacy of Targeted 5-day Combined Parenteral and Intramammary treatment of Clinical Mastitis Caused by PenicillinSusceptible or Penicillin-Resistant Staphylococcus aureus. Acta Vet. Scand. 44, 53-62.

36. TENHAGEN, B. A., G. KÖSER, J. WALLMANN and W. HEUWIESER (2006): Prevalence of Mastitis Pathogens and Their Resistance Against Antimicrobial Agents in Dairy in Brandenburg, Germany. J. Dairy Sci. 89, 2542-2551.

37. TOMŠE-ĐURANEC V., N. KRNJAK, I. TUMPEJ, A. DAKIĆ, V. PINTIĆ, D. ČUKLIĆ, T. JELEN, N. PINTIĆ-PUKEC, M. BORČIĆ, D. STRUČIĆ, D. BLAŽEK, T. HORVAT, I. GRGIČIN i Z. ĐURIČIĆ (2008): Vodič dobre higijenske prakse u proizvodnji mlijeka. Nakladnik Koprivničkokriževačka županija, Projekt EU i Program Phare $\mathrm{CBC} /$ Interreg III A.

38. TURUTOGLU, H., S. ERCELIK and D. OZTURK (2006): Antibiotic resistance of Staphylococcus aureus and Coagulase-negative staphylococci isolated from bovine mastitis. Bull. Vet. Inst. Pulawy 50, 41-45.

39. WAWRON, W., M. BOCHNIARZ, T. PIECH, J. WYSOCKI and M. KOCIK (2013): Antimicrobial susceptibility of Prototheca zopfii isolated from bovine mastitis. Bull. Vet. Inst. Pulawy 57, 485-488. 


\section{Antimicrobial susceptibility of bovine mastitis pathogens from northwestern Croatia in the period 2014 to 2018}

Tomislav SUKALIĆ, DVM, PhD, postdoctorand, Ivica PAVLJAK, DVM, MSc, Assistant, Ana KONČURAT, DVM, PhD, Scientific Accociate, Željko CVETNIĆ, DVM, PhD, Academician, Branko BAČANEK, DVM, MSc, retired, Jadranka JURMANOVIĆ, DVM, MSc, retired, Croatian Veterinary Institute - Regional Department Križevci, Croatia; Dražen ĐURIČIĆ, DVM, PhD, Assistant Professor, Mount-trade, Garešnica, Croatia; Jozo GRBAVAC, DVM, PhD, Associate Professor, Faculty of Agriculture and Food biotechnology University of Mostar, Bosnia and Herzegovina; Marko SAMARDŽIJA, DVM, PhD, Full Professor, Faculty of Veterinary Medicine University of Zagreb, Croatia

This paper summarises the results of microbiological testing of milk samples from cows suffering from mammary gland inflammation. The examined samples were delivered to the Diagnostic Laboratory of the Križevci Veterinary Institute over a 5-year period, originating from seven counties in northwestern Croatia. Samples were screened by conventional microbiological methods under aerobic conditions. A total of 1264 samples were processed, and a positive result was found in 983 cases (77.76\%). In total, 967 strains of bacteria were isolated, while nine samples contained yeast and seven contained algae. Susceptibility to antimicrobial drugs was determined by the disk diffusion method. Among the positive microbiological findings, $14.24 \%$ of the isolates belonged to the species Staphylococcus aureus (S. aureus), and $60 \%$ of these were oxacillin-resistant. $S$. aureus strains showed the highest susceptibility to AMC (91.4\%) and CEQ (90.7\%). Coagulase-negative staphylococci (CNS) accounted for $19.23 \%$ of positive cases, with the highest sensitivity to CEQ (84.6\%). Streptococcus agalactiae was found in $3.36 \%$ of positive samples and showed

good susceptibility to CPZ and CEQ (87.9\%). Other streptococci (according to Lancefield group C, D and others) accounted for $39.47 \%$ of positive findings. They showed the highest sensitivity to AMC (95.4\%), and CEQ $(92.8 \%)$. Among the Gram-negative bacteria, Escherichia coli (9.46\%) was the most common finding, followed by the genera Pseudomonas, Enterobacter and Klebsiella $(3.46 \%, 2.64 \%$ and $0.1 \%$, respectively). Yeasts (Candida spp.) and algae (Prototheca spp.) were isolated in less than $1 \%$ of cases. The results show that the percentage of staphylococcal and streptococcal mastitis is similar to previous reports, though an increasing trend in the number of resistant strains of $S$. aureus was noted. A reliable microbiological finding with an antimicrobial susceptibility test, accompanied with clinical examination is the foundation of mastitis control in our conditions, as different types of microorganisms require different treatment approaches, such as antibiotic selection, vaccination, various drying-off practices, or exclusion of the animal as a last choice.

Key words: bovine mastitis; pathogens; antimicrobial susceptibility; milk 